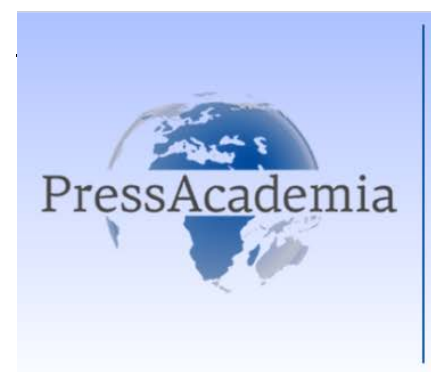

Press Academia Procedía

Global Business Research Congress (GBRC), May 26-27, 2016, Istanbul, Turkey.

\title{
AN EMPIRICAL STUDY ON THE GENERATION X AND Y FOR DETERMINING ORGANIZATIONAL COMMITMENT DIFFERENCES
}

DOI: 10.17261/Pressacademia.2016118629

\section{Murat Koc ${ }^{1}$, Linda Ozturk ${ }^{2}$, Adem Yildirim ${ }^{3}$}

Çağ Üniversitesi. muratkoc@cag.edu.tr

Çağ Üniversitesi. lindaozturk1@hotmail.com

Çağ Üniversitesi.yildirim adem@mynet.com

\begin{abstract}
It is important to know that a number of features among the generations, the similarities and differences in the context of organizational behaviour. This study examined in organizational commitment in the context of the $\mathrm{X}$ and $\mathrm{Y}$ generations differences. For this purpose, the dimensions of organizational commitment; "emotional attachment", "continuing commitment" and "normative commitment" and "jobsatisfaction" have been described separately. Then, in accordance with data, demographic variables are listed by the means of the relationship between the variables and dimensions. This search was conducted with 455 employees in Kahramanmaraş Industrial Center.
\end{abstract}

Keywords: $X$ and $Y$ generation, organizational commitment, job satisfaction.

JEL Codes: J40, M10, M12.

\section{VE Y KUŞAĞININ ÖRGÜTSEL BAĞLILIK FARKLILIKLARINI BELIRLEMEYE YÖNELIK AMPIRIKK BIR ÇALIŞMA}

\section{ÖZET}

Kuşaklar arasındaki bir takım özelliklerin, benzerliklerin ve farklılıkların bilinmesi önem taşımaktadır. Bu çalışmada örgütsel bağlılık X ve $Y$ kuşaklarının farklılığı bağlamında incelenmiştir. Bu amaçla örgütsel bağlılığın alt boyutları olan "duygusal bağlılık", "devam bağlılığı" ve "normatif bağııık" ile "iş tatmini" arasındaki ilişkiler ayrı ayrı açıklanmıştır. Ardından elde edilen veriler doğrultusunda, demografik değişkenler, bağımlı ve bağımsız değişkenler ile bu değişkenlerin alt boyutları arasındaki ilişkiler belirtilmiştir. Araştırma Kahramanmaraş İlinde $X$ ve $Y$ kuşağı üyesi olan 455 çalışandan anket yöntemi ile veriler toplanarak yapılmıştır. Araştırmaya katılanlara; Minnesota İş Tatmini Ölçeği' nin yanı sıra Örgütsel Bağlılık Ölçeği olarak Allen ve Meyer' in 1990' da geliştirdikleri üç bileşenli (duygusal, devam ve normatif) bağııık ölçeği ve kişisel bilgi formu uygulanmıştır. Çalışmada farklı sektörlerden veri toplanmıştır. Cinsiyet, eğitim düzeyi, medeni durum, ünvan, çalışılan bölüm, sektör yapısı ve endüstri şekli dikkate alınarak $X$ ve $Y$ kuşaklarının farklılıkları incelenmiş, örgütsel bağlılık ve iş tatminine etki eden faktörlerin bulunması ve farklılıkların belirlenmesi hedeflenmiştir.

Anahtar Kelimeler: $Y$ ve $X$ kuşağı, örgütsel bağlılık, iş tatmini.

JEL Kodları: J40, M10, M12. 


\section{GiRiş}

İnsan kaynağının örgütlerin belirlenen hedeflere ulaşmasındaki rolü, endüstrilerin temel başarı faktörleri arasında sayılmaya başlamıştır. Çalışanların yaptıkları işten ve çalıştıkları örgütten memnun olmalarını sağlamak, artık örgütler tarafından üretim yapmak ya da satışı artırmak kadar önemli hale gelmiştir (Öztürk 2013). Çalışanların tatminini artırmak ve özellikle örgütsel bağıılığı sağlamak; örgütsel performansı pozitif yönde etkilemekte, işe geç gelme, devamsızlık ve işten ayrılma gibi istenmeyen sonuçları azaltmaktadır. Bağlılı̆ı yüksek olan çalışanların, görevlerini yerine getirme ve örgütsel hedeflere ulaşmada ekstra çaba sarf ettikleri ve bağlıı̆̆ın aynı zamanda çalışanları problem çözebilen insanlar haline getirdiği vurgulanmaktadır (Arı, 2015:16). Bu nedenlerle işletmelerin, çalışanların tatmin ve bağlılık düzeylerini artırma çabası gün geçtikçe daha çok önem kazanmaktadır. Ayrıca çalışanların gerekli tatmin ve bağlılıklarının artırılabilir düzeyde yönetilebilir ve yönlendirilebilir etken değişkenlere ihtiyaç duyduğu bir gerçektir. Bu değişkenlerden biri olan kuşak kavramı da son dönmelerde üzerinde önemle durulan ve araştırılan konulardan biri haline gelmiştir (Gürbüz, 2015:40) Nitekim çalışma yaşamında bulunan her bir kuşağın temel değerleri, iş ve örgüte yönelik tutumları farklılık göstermektedir. Bu nedenle şirketlerin, kuşakların beklenti, arzu ve isteklerine uygun uygulamalarla stratejiler geliştirmesi elzem hale gelmiştir.

\section{KAVRAMSAL ÇERÇEVE}

\section{1. Örgütsel Bağlılık}

Örgütsel bağııık; çalışanların işe ve örgüte karşı tutumlarının ve niyetlerinin davranışsal bir göstergesidir. Bu noktada bağııık; çalışanın, ait olduğu örgüte karşı sadakat, örgüt başarısına ilgi ve örgütüne karşı hissettiği bağın gücünü ifade etmektedir (Arı, 2015:15). Örgütsel bağlılık, "Belli bir örgütün üyesi olarak kalmaya güçlü bir istek, örgüt adına yüksek düzeyli çaba gösterme isteği ve örgütün değerlerine ve hedeflerine inanılması, benimsenmesi" (...) "çalışanların örgütün amaç ve değerlerini dayatma olmaksızın kabul etmeleri, içselleştirmeleri; bu amaç ve değerler doğrultusunda örgütün etkinlik ve başarıya ulaşması için çaba göstermeye istekli olmalarıdır" (Karcıoğlu ve Türker, 2010:127). Diğer tanımlamalara göre de örgütsel bağlılık; kişinin kendini tamamiyle işine vermesi, kişinin örgütüne önem verme eğiliminde olması ve kişinin örgütüne bağılık duyması, çalışanların o örgütün faydasına olan amaçlara ve değerlere duygusal bir şekilde bağlanması veya bir örgütün üyesi olarak kalmak için güçlü bir istek duyması, gayret göstermesi, amaç ve değerlerine inanç duyması şeklinde tanımlamaktadır (Sözmez, 2014:53).

Bağlılık, çalışanın psikolojik koşullarının önemli bir parçasıdır (Albdour ve Altarawneh, 2014:194). Bireyler örgütle ve örgütün amaçları ile kendilerini özdeşleştirmekte ve bu amaçları gerçekleştirmek adına örgüte bağlılık davranışı göstermektedirler (Arı, 2015:15). Bu noktada bağlılık; bireyler örgütleriyle özdeşleştiklerinde ve örgütsel amaç ve değerler yönünde çaba sarf ettiklerinde ortaya çıkmaktadır. Bu bağ, örgüt ile birey arasında aktiftir, çünkü bireyler örgütün daha iyiye gidebilmesi için kendileriyle ilgili fedakarlıklar yapmakta (Sözmez, 2014:54) ve örgüte güçlü bir inanç ile örgüt üyeliklerini koruma çabası içinde olmaktadırlar (Albdour ve Altarawneh, 2014:194). Esasında örgütsel bağlılık, kısaca, kişinin örgütle özdeşleşmesinin ve örgüte katılımının gücüdür (Öztürk, 2013:9).

Bağlılık kavramının özünde aidiyet duygusunun yer aldığı ve örgütsel bağlılığın, çalışanları problem üreten değil, problem çözen bireyler haline getirdiği (Arı, 2015:16) ve örgüt yararına oluşan örgütsel vatandaşlık faaliyetlerini doğurduğu (Albdour ve Altarawneh, 2014:194) vurgulanmaktadır. Örgütsel bağlılık, örgütsel başarının arkasındaki sürükleyici güç olarak nitelendirilmektedir (Öztürk, 2013:12). Örgütüne bağlılık gösteren çalışanların, daha üretken, sadakatlerinin yüksek, verimlilik ve sorumluluk duygularının daha fazla olduğu öne sürülmektedir (Arı, 2015:16). Ayrıca örgüt üyesinin kendisini örgütle birlikte tanımlaması, örgütsel değişimi kabul etme derecesi, örgütsel verim artışı, üretkenlik ve işgücü devri, performans, memnuniyet gibi anlamlı iş sonuçları üzerinde etkili ve önemlidir (Albdour ve Altarawneh, 2014:194; Arı, 2015:15).

Örgütsel bağlılık, beş nedenden dolayı örgütler için yaşamsal bir konu haline gelmiştir. Bu kavram ilk olarak iş bırakma, devamsızlık, geri çekilme ve iş arama faaliyetleri ile; iş doyumu, işe sarılma, moral ve performans gibi tutumsal bilişsel yapılara; üçüncü olarak özerklik, sorumluluk, katılım, görev anlayışı gibi iş görenin işi ve rolüne uygun özelliklerle, dördüncü olarak yaş, cinsiyet, hizmet süresi ve eğitim gibi iş 
görenlerin kişisel özellikleriyle ve son olarak bireylerin sahip olduğu bireysel bağlılık kestiricilerini bilmeyle yakından ilişkilidir (Karcıoğlu ve Türker, 2010:127).

Örgütsel bağılı̆ğın etkili biçimde değerlendirilmesi amacıyla, örgütsel bağılık sınıflandırması konusunda gerçekleştirilen ilk çalışmalardan biri, Meyer ve Allen tarafından ortaya konulan üç boyutlu örgütsel bağılık modelidir. Bu modele göre çalışanlar örgütlerine Duygusal, Devam ve Normatif Bağlıık olmak üzere üç farklı tipte bağlılık hissetmektedirler.

Duygusal Bağııık: Bireyin, örgütün hedef, değer ve amaçlarıyla kendi değer ve amaçlarını özdeşleştirmesi sonucu ortaya çıkan bağılııtır. Birey, örgüte karşı duygusal anlamda bağlanmakta ve aidiyet duygusu taşımaktadır. Birey, özgür iradesiyle hedefleri gerçekleştirmek için ücret, çalışma koşulları gibi somut konularda ve örgüt değerlerini benimsemek gibi soyut konularda örgüt lehine fedakarlıkta bulunmaktadır. Olumlu iş deneyimleri sonucunda da duygusal bağ|lığın gelişimi oluşmaktadır. Duygusal bağ|ılığın gelişimi de, verimlilik üzerinde pozitif etki yaratmakta ve çalışanın iş tatminini artırmaktadır (Meyer ve Allen, 1991; Kaur ve Sandhu2010).

Devam Bağlıığı: Bireyin örgüt üyeliğini sürdürmeyi istemesi durumunda ortaya çıkan bağlııktır. Örgütten ayrımanın getireceği maliyetlerin farkında olunması neticesinde çalışan; örgütte çalıştığı süre içerisinde harcadığı emek, zaman ve çaba ile edindiği statü, para gibi kazanımlarını örgütten ayrılmasıyla birlikte kaybedeceği veya iş bulma alternatiflerinin azlığı düşüncesiyle örgüte bağlılı̆ını sürdürmektedir. Bu düşünce ile oluşan bağlıık tipi devam bağılıı̆ı olarak adlandırılmaktadır (Karcıoğlu ve Türker, 2010:128).

Normatif Bağlıık: Normatif bağlıık, bireyin örgütün iş görenlerinden sadık olmalarını beklediğine dair inancıdır. Birey, örgütte kaldığı sürece ahlaki yükümlülük hissetmektedir. Örgütün amaç, politika ve faaliyetlerini gerçekleştirmeyi bir görev olarak adledmektedir. Kendini örgüte adama ve sadakat gösterme kavramları ile yakın ilişkili olan bu bağııık tipi ahlaki duygulara dayanmaktadır (Kaur ve Sandhu 2010:142Öztürk, 2013:21; Arı, 2015:20).

Bu bağılıık sınıflandırmasının üç tipinde de çalışan örgütte bulunmaya devam etmeyi istemektedir. Ancak duygusal bağ|lııkta örgütte kalma güdüsü isteğe, devam bağ|lığında gereksinime ve normatif bağlılıkta ise yükümlülüğe dayanmaktadır (Sönmez, 2014:61; Arı, 2015:19-20).

\subsection{Iş Tatmini}

Üzerinde uzlaşılmış bir tanımı bulunmayan iş tatmini, Herzberg (1987)' e göre; çeşitli değer sistemleri içinde olan çalışanın, işe karşı tutumunu ifade etmektedir. Vroom ise; iş tatminini, çalışanın işindeki rolüne ilişkin duygusal tepkisi olarak tanımlamaktadır. Çalışanın, işine karşı olumlu tepkisi iş tatmini olarak nitelendirilirken, olumsuz tepkisi ise iş tatminsizliği olarak ifade edilmiştir (Vroom' dan aktaran Bayrak Kök, 2006:293). İş tatmini; işten duyulan hoşnutluk/hoşnutsuzluk, memnuniyet; çalışanın, yapmış olduğu işten dolayı kendini iyi hissetme derecesi ve/veya yaptığı işi değerlendirmesi sonucunda hissettiği olumlu duygusal durum olarak da farklı şekillerde tanımlanmıştır (Dağdeviren Gözen, 2007:2; Mert, 2010:122; Akşit Aşık, 2010:34; Robbins ve Judge, 2013:77; Sönmez, 2014:5; Koç vd., 2015:494). Hoppock; iş tatminini çalışanın psikolojik, fizyolojik ve çevresel koşulların herhangi bir kombinasyonu olarak işten duyulan memnuniyet olarak tanımlamıştır (Hoppock' tan aktaran Aziri, 2011:77). Greenberg ve Baron' a göre; çalışanın yaptığı işe karşı genel tutumu (Greenberg ve Baron' dan aktaran Akşit Aşık, 2010:34), Locke' a göre, kişinin işini ya da iş deneyimlerini değerlendirmesinden kaynaklanan keyifli veya pozitif duygusal durum olarak açıklanmıştır (Locke' dan aktaran Judge ve Klinger, 2008:394).

iş tatmini, çalışanların fizyolojik ve ruhsal sağlıklarının yanında duygularının da bir belirtisidir (Akıncı, 2002:3; Koç vd., 2015:494). Çalışanların işle ilgili beklentileri ile işten elde ettiklerini karşılaştırmaları sonucu ortaya çıkmaktadır. Çalışanların işlerinin çeşitli yönlerine karşı beslemiş oldukları tutumların toplamı olarak da ifade edilebilir. Bu çerçevede, çalışanın işiyle ilgili genel tutumu olumlu ise iş tatmini ortaya çıkmakta; aksi halde tatminsizlikten söz edilmektedir (Çarıkçı, 2000:155). İ̧ tatmini; çalışanların, bireysel tutum ve davranış modellerini anlamada ve güven, bağlıık, verimlilik gibi çıktıların elde edilmesinde önemli özellikler taşımaktadır (Judge ve Klinger, 2008:394; Sönmez, 2014:6). İ̧ tatminini etkileyen pek çok faktör bulunmaktadır. Ancak genel olarak iş tatminini etkileyen iki ana faktörden bahsedilmektedir. Birincil faktörün; bireyin kişisel durumu; yaş, 
cinsiyet, eğitim, statü, sosyo-kültürel çevre, kişilik, bireyin yapısı, duyguları, düşünceleri, istekleri ile içinde bulunduğu intiyaçlar ve bunların şiddet dereceleriyle ilgili olduğu, ikincil faktörün ise, işe yönelik şartlar olduğudur. İşe yönelik şartlar; kurumun işleyişi ve politikaları, fiziksel koşullar, ücret, terfi olanakları, denetim ve iş arkadaşları gibi faktörleri kapsamaktadır. Bu faktörler, çalışanın haz alma derecesine bağlı olarak tatmin ya da tatminsizlik hissetmesine etki etmektedir (Bayrak Kök, 2006:293; Aksu, 2012:63).

\subsection{X ve $Y$ Kuşağı}

Aynı dönemlerde yaşayan, belirli olgulara ve olaylara yönelik ortak bir bilinç, fikir ve deneyimlere sahip bireylerin oluşturduğu gruplar olarak tanımlanan kuşak; benzer değer sistemlerini yansıtmaları bakımından sınıflandırılmaktadır (Cox ve Holloway, 2010:63; Peitzmeier, 2011:8; Gürbüz, 2015:41). Aynı kuşağın üyeleri; duyguların, tutumların, tercihlerin ve kişisel özelliklerin oluşturduğu toplu bir kültürel alanı paylaşmaktadırlar. Benzer normlara sahip olan kuşak grupları benzer iş değerleri ve iş tutumu hususunda da aynı özellikleri gösterebilmektedirler (Torun ve Çetin, 2015:139). Bu sınıflandırma; "farklı kuşakların bakış açıları ve çalışma tarzlarını anlamlandırabilmek ve sağlıklı bir kültürel yapının inşasını sağlayabilmek için” zorunlu hale gelmektedir (Adıgüzel vd., 2014:170). Aynı yıllarda doğan gruplar olarak da nitelenen kuşak ayrımı, konumuz kapsamında yalnızca $X$ ve $Y$ kuşakları açısından ele alınmış ve yıllar itibariyle X Kuşağının doğum aralığı 19651979; Y Kuşağının doğum aralığı ise, 1980-2000 olarak ele alınmıştır.

X Kuşağının benzer normları; İ̧̧ yerine bağlı, , iş ortamında esneklik ve otonomiyi tercih etme, iş motivasyonları yüksek, otoriteye saygılı, aynı işte uzun yıllar çalışabilme, kendi sorunlarını çözme yetisi, aile ve iş dengesi arayışı, kanaatkâr, gerçekçi, kaygılı, şüpheci, amaç ve görev odaklı olmanın yanında X kuşağı iş hayatına dair çok az beklentiye sahiptir (Herley, 2009:8; Gürbüz, 2015:42; Öz, 2015:10; Torun ve Çetin, 2015:139).

Sürekli "neden" sorusunu soran Y kuşağının ortak normları; işine eğlence katmayı sevme, internet ve teknoloji bağımlılı̆̆, kişisel iletişime önem verme, aktif, takım halinde çalışmaktan hoşlanma, aynı anda birçok şeyi yapabilme, iş değiştirme alışkanlıkları fazla, işten çok çabuk sıkılabilen, otoriteyi reddetme, esnek çalışma saatleri tercihi, ilgi odağı olma, yüksek beklenti ve belirgin hedefler, kendine güven, başarı, yüksek adaptasyon, bilgiye erişme hızı, işte çabuk yükselme, kariyer gelişimlerini kendi kendilerine planlama eğilimi, sorumluluk almaya istekli olmalarıdır. $Y^{\prime}$ ler için aile ve arkadaşlar işten daha önceliklidir. Yöneticilerin her bir çalışana bireysel önem vermeleri gerektiğini düşünürler (Herley, 2009:8; Keleş, 2011:131; Adıgüzel vd., 2014:173; Alparslan ve Sezgin, 2014:841; Gürbüz, 2015:42; Öz, 2015:12; Koç vd., 2015:493; Torun ve Çetin, 2015:139). Ayrıca Karaaslan (2014:134)' nın gerçekleştirdiği çalışma bulgularına göre, $X$ ve $Y$ kuşağının iş motivasyonundaki ortak özelliği iletişimdir. Ancak, bu iletişim kriterleri; X kuşağında bir tercih iken, Y kuşağında bir koşuldur.

\subsection{Konu İle İlgili Önceki Araştırmalar}

Brezilya'da faaliyet gösteren 394 firmadan 102.540 katılımcı ile gerçekleştirilen çalışmada; X ve $Y$ kuşağı arasındaki örgütsel bağlılığın temel belirleyicisinin liderlik faktörü olduğu tespit etmiştir. Özellikle koruyucu ve babacan karaktere sahip liderlerle çalışan Y kuşağı çalışanlarının organizasyonel bağlılığının daha yüksek olduğu sonucuna ulaşılmıştır (Da Silva vd., 2012). Kian ve Yusoff (2012)' un çalışmasında ise, Malezya'daki elektrik ve elektronik endüstrisinde çalışan 124 kişi ile gerçekleştirilen çalışma sonucunda; Y kuşağının X kuşağına göre içsel ve dışsal faktörler çerçevesinde daha az motive oldukları ve örgütsel bağlıklarının $X$ kuşağına göre daha az olduğu tespit edilmiştir. Rajput vd. (2012)' nin bilişim sektöründe faaliyet gösteren bir firmadaki 150 çalışanın iş-özel hayat ve organizasyonel bağlılık açısından değerlendirdikleri araştırmada; Örgütsel bağıılı̆̆ın X kuşağının Y kuşağına göre daha fazla olduğu tespit edilmiştir. Ancak $Y$ kuşağının iş ve özel hayat arasındaki dengenin sağlandığı ölçüde örgütsel bağıılığının arttığı tespit edilmiştir. Khanolkar' ın (2013), Hindistan/Bombay şehrindeki 245 Y kuşağı çalışanın olduğu firmada yaptığı analizde, Y kuşağının kendi karakteristik yapısına uygun firmalarda örgütsel bağıılıklarının daha yüksek olduğu ortaya çıkmıştır. Sönmez (2014), iş tatmini ve örgütsel bağlılık konusundaki çalışmasında yaş değişkenine yönelik olarak; çalışanların yaşlarının artmasıyla birlikte, içsel ve dışsal iş tatmini ve örgütsel bağ|ıık düzeylerinin arttığını tespit etmiştir. Duygusal bağlılık boyutu için 39 yaş ve üstü yaş grubundaki çalışanların duygusal bağlılık düzeyinin, 25-31 yaş grubundaki çalışanların duygusal bağlılık düzeyinden ve 18-24 yaş grubundaki çalışanların duygusal bağlılık düzeyleri ise bir önceki yaş grubunun bağlılık düzeyinden daha fazladır. Aynı şekilde, yaş arttıkça yapılan işten duyulan genel iş tatminini de artmaktadır. Gürbüz (2015) ise; “ Kuşak Farklılıkları: Mit mi, Gerçek mi?” çalışmasında Ankara'da yedi farklı iş 
kolunda istihdam edilen 731 çalışandan oluşan bir veri seti ile, analiz gerçekleştirmiştir. Bulgulara göre, çalışanların örgütlerine yönelik "duygusal bağlılık" düzeyleri ile iş ahlakı boyutlarından birisi olan "boşa zaman geçirmeme" değişkenleri, kuşak gruplarına göre anlamlı düzeyde farklılık göstermiştir. Kuşakların duygusal bağlılık değişkeni üzerindeki etkisi düşük olmakla birlikte anlamlı olduğu görülmüş ve buna göre, $X$ kuşağının, $Y$ kuşağına göre duygusal bağlılığı daha yüksek grup olarak tespit edilmiştir. Çalışma yaşamındaki en geç kuşak olan Y kuşağının, bağlılık düzeyleri en düşük grup olarak ortaya çıkmıştır.

\section{ARAŞTIRMA METODOLOJISI}

Çalışmada, $X$ ve $Y$ kuşaklarının örgütsel bağıılık ve iş tatmin düzeyleri arasındaki farklılıklar ortaya konulmaya çalışılmıştır. Bu amaçla; X ve Y Kuşağı ile "iş tatmini” ve örgütsel bağlılığın alt boyutları olan "duygusal bağlılık", "devam bağııı̆ı", "normatif bağlıık" arasındaki ilişkiler açıklanmaya çalışılmıştır. Anket tekniğinden faydalanılan çalışma üç bölümden oluşmaktadır. Bu kapsamda birinci bölümde, çalışanların iş tatminlerini ölçmek için literatürde en çok kullanılan "Minnesota İş Tatmini Ölçeği” kullanılmıştır. Bu ölçekte iş tatmini ile ilgili içsel ve dışsal boyutlar araştırma kapsamına alınmıştır (20 soru). İkinci bölümde, örgütsel bağlılığı ölçmek için, Allen ve Meyer'in "3 Boyutlu Örgütsel Bağlılık Modeli" kullanılmıştır (16 soru). Üçüncü bölümde ise, demografik verileri içeren sorulara yer verilmiştir (8 soru). Veriler, Kahramanmaraş illinde, farklı iş kollarında istihdam edilen $X$ ve $Y$ kuşağı üyesi olan 467 çalışandan toplanmıştır. Ancak bunların 12 tanesi hatalı, eksik ve yaş grubuna uymaması nedeniyle elenmiş ve araştırma kapsamına yalnızca 455 kişinin verileri dahil edilmiştir. Verilere, SPSS programı aracılığı ile Anova ve Korelasyon analizleri uygulanmıştır. Gerçekleştirilen çalışma, \% 95 güven aralığına sahiptir.

Genel olarak literatür tarandığında, araştırma sonuçlarının kuşakların değer ve tutumları arasında farklıııklar olduğu görüşüne dayanmakta ve ampirik bulgularıyla desteklenmektedir. Çalışma amaç ve hipotezleri, literatür doğrultusundaki verilerden faydalanılarak belirlenmiştir.

\section{Araştırmanın Hipotezleri}

H1: İş tatmini ile örgütsel bağlılık arasında, istatistik açıdan pozitif yönde ve anlamlı bir ilişki vardır.

H2: İş tatmini ve örgütsel bağlılık ile kuşak değişkeni (yaş) arasında, istatistik açıdan pozitif yönde ve anlamlı bir ilişki vardır.

H3: İş tatmini ve örgütsel bağıılık ile cinsiyet arasında, istatistik açıdan pozitif yönde ve anlamlı bir ilişki vardır.

H4: İş tatmini ve örgütsel bağlılık ile medeni durum arasında, istatistik açıdan pozitif yönde ve anlamlı bir ilişki vardır.

H5: İ̧ tatmini ve örgütsel bağlılık ile çocuk sayısı arasında, istatistik açıdan pozitif yönde ve anlamlı bir ilişki vardır.

H6: İş tatmini ve örgütsel bağlılık ile unvan arasında, istatistik açıdan pozitif yönde ve anlamlı bir ilişki vardır.

H7: İş tatmini ve örgütsel bağlılık ile çalışma süresi arasında, istatistik açıdan pozitif yönde ve anlamlı bir ilişki vardır.

H8: İ̧̧ tatmini ve örgütsel bağlııı ile gelir arasında, istatistik açıdan pozitif yönde ve anlamlı bir ilişki vardır.

\section{VERILERIN ANALIZI VE BULGULAR}

Yapılan araştırmanın doğruluğunu ve tutarlılığını ölçmek için güvenirlik testi uygulanmıştır. İstatistik açıdan güvenirliği ölçmek için, çok maddeli bir ölçekte iç tutarlılığın değerlendirilmesinde en çok kullanılan Cronbach Alpha ölçüsü kullanılmıştır. Cronbach Alfa testi hem boyutlar açısından hem de ölçeğin tümüne uygulanarak test edilmiştir. 
Tablo 1: Güvenirlik Analiz Sonuçları

\begin{tabular}{|c|c|c|}
\hline & Değerlendirilen Soru Sayısı & Alpha Değeri \\
\hline \multicolumn{3}{|l|}{ İş Tatmini } \\
\hline İçsel Tatmin Düzeyi & 13 & ,912 \\
\hline Dışsal Tatmin Düzeyi & 7 & ,845 \\
\hline Genel Tatmin Düzeyi & 20 & ,937 \\
\hline \multicolumn{3}{|l|}{ Örgütsel Bağlılık } \\
\hline Duygusal Bağlılık & 8 & ,899 \\
\hline Devam Bağ|ılığı & 4 & ,865 \\
\hline Normatif Bağlılık & 4 & ,844 \\
\hline Toplam Örgütsel Bağlılık & 16 & ,925 \\
\hline
\end{tabular}

Tablo 1' de görüldüğü üzere, İş Tatmini açısından; Dışsal Tatmin Düzeyi (,845) oldukça güvenilir, İçsel Tatmin Düzeyi $(, 912)$ ile Genel Tatmin Düzeyi $(, 937)$ ise yüksek derecede güvenilir değere sahiptir. Örgütsel Bağlılık açısından ise; Duygusal Bağlılık (,899), Devam Bağlılığı $(, 865)$, Normatif Bağlılık $(, 844)$ ve Toplam Örgütsel Bağıılığın (,925) Alpha değeri yüksek derecede güvenilirdir.

Tablo 2: Demografik Veriler

\begin{tabular}{|c|c|c|c|}
\hline \multicolumn{2}{|c|}{ Değişkenler } & Frekans (n) & Yüzde (\%) \\
\hline \multirow{2}{*}{ Cinsiyet } & Erkek & 414 & 91,0 \\
\hline & Kadın & 41 & 9,0 \\
\hline \multirow{2}{*}{ Medeni Durum } & Evli & 366 & 80,4 \\
\hline & Bekar & 89 & 19,6 \\
\hline \multirow{4}{*}{ Çocuk sayısı } & çocuk yok & 144 & 31,6 \\
\hline & 1 çocuk & 58 & 12,7 \\
\hline & 2 çocuk & 118 & 25,9 \\
\hline & 3 ve daha fazla çocuk & 135 & 29,7 \\
\hline \multirow{3}{*}{ Eğitim } & ilköğretim & 283 & 62,2 \\
\hline & Lise & 129 & 28,4 \\
\hline & Üniversite & 43 & 9,5 \\
\hline \multirow{3}{*}{ Çalışma süresi } & 1 yıldan az & 164 & 36,0 \\
\hline & 1-4 yıl arası & 183 & 40,2 \\
\hline & 5 yıl ve üstü & 108 & 23,7 \\
\hline \multirow{2}{*}{ Yaş aralığı } & $18-35$ & 276 & 60,7 \\
\hline & $36-52$ & 179 & 39,3 \\
\hline \multirow{3}{*}{ Gelir } & 1000も ve altı & 308 & 67,7 \\
\hline & 1001-2000も & 126 & 27,7 \\
\hline & 2001も ve üstü & 21 & 4,6 \\
\hline \multirow{2}{*}{ Ünvan } & $\begin{array}{l}\text { Alt kademe çalışan } \\
\text { (iş gören) }\end{array}$ & 434 & 95,4 \\
\hline & $\begin{array}{l}\text { Üst kademe çalışan } \\
\text { (yönetici) }\end{array}$ & 21 & 4,6 \\
\hline Toplam & & 455 & 100,0 \\
\hline
\end{tabular}

Demografik verilere ilişkin elde edilen bulgular ise, Tablo 2' de yer aldığı üzere; \%91 erkek, \% 9 kadın çalışanlardan, \%80,4' ü evli ve \%19,6' sı bekarlardan oluşmaktadır. 144 kişinin çocuğu bulunmazken, 1 çocuğa sahip olanlar 58 kişi, 2 çocuğa sahip 118 kişi, 3 ve daha fazla çocuğa sahip olanlar 135 kişidir. Çoğunluğu 
ilköğretim mezunudur (\%62,2). Aynı iş yerinde, 1 yıldan az süredir çalışanlar 164, 1-4 yıl arası 183, 5 yıl ve üstü yıldır çalışanlar 108 kişidir. 276' sı Y kuşağı ve 179' u X kuşă̆ıdır. Çalışanların büyük bölümü (308 kişi) 1000も ve altında maaş almaktadır. 434 kişi alt kademede çalışırken, üst kademede çalışanların sayısı 21' dir.

Tabı0 3: İş Tatmini ile Örgütsel Bağlılık Arasındaki Korelasyon

\begin{tabular}{|l|l|c|c|}
\hline \multicolumn{2}{|c|}{} & Genel İş Tatmini & Toplam Örgütsel Bağlılık \\
\hline \multirow{2}{*}{ Genel İş Tatmini } & Korelasyon Katsayısı & 1 &, 600 \\
\cline { 2 - 4 } & Anlamlılık Düzeyi & &, 000 \\
\hline \multirow{2}{*}{ Toplam Örgütsel Bağııık } & Korelasyon Katsayısı &, 600 & 1 \\
\cline { 2 - 4 } & Anlamlılık Düzeyi &, 000 & \\
\hline
\end{tabular}

Gerçekleştirilen korelasyon analizinde; Tablo 3' de görüldüğü gibi, Genel İ̧̧ Tatmini ve Toplam Örgütsel Bağllıık arasında pozitif yönde anlamlı sonuçlara ulaşılmıştır. Ayrıca alt boyutlar açısından da değerlendirilen analiz sonucunda; genel tatmin düzeyinin alt boyutları olan, içsel tatmin $(p, 000)$ ve dışsal tatmin $(p, 000)$ boyutları ile örgütsel bağlılığın alt boyutları olan, duygusal bağlılık $(p, 000)$, devam bağılı̆̆ı $(p, 000)$ ve normatif bağlılık ( $p$ ,000) arasında da istatistiki açıdan anlamlı sonuçlara ulaşılmışır. Böylece "H1: İ̧̧ tatmini ile örgütsel bağılıı arasında, istatistik açıdan pozitif yönde ve anlamlı bir ilişki vardır" hipotezi kabul edilmiştir.

Analiz sonuçlarına göre, elde edilen bulgularda; iş tatmini ve örgütsel bağılıık ile tüm alt boyutların sınandığı istatistiki verilerde kuşak (yaş), cinsiyet, medeni durum ve çocuk sayısı arasında anlamlı sonuçlara ulaşılamamışıı. Bu bulgular ışığında; "H2: İş tatmini ve örgütsel bağııık ile kuşak değişkeni (yaş) arasında, istatistik açıdan pozitif yönde ve anlamlı bir ilişki vardır", "H3: İş tatmini ve örgütsel bağlıık ile cinsiyet arasında, istatistik açıdan pozitif yönde ve anlamlı bir ilişki vardır", "H4: İ̧̧ tatmini ve örgütsel bağlılık ile medeni durum arasında, istatistik açıdan pozitif yönde ve anlamlı bir ilişki vardır" ve "H5: İ̧̧ tatmini ve örgütsel bağlıık ile çocuk sayısı arasında, istatistik açıdan pozitif yönde ve anlamlı bir ilişki vardır" hipotezleri reddedilmiştir.

Tablo 4: İ̧ Tatmini ve Örgütsel Bağlılık ile Unvan Arasındaki Korelasyon

\begin{tabular}{|ll|c|}
\hline & Unvan & p \\
\hline Genel işs Tatmini & &, 006 \\
\hline & İçsel Tatmin &, 017 \\
\cline { 2 - 3 } & Dışsal Tatmin &, 003 \\
\hline Toplam Örgütsel Bağlılık & &, 002 \\
\hline & Duygusal Bağ|lıık &, 006 \\
\cline { 2 - 3 } & Devam Bağ|lığı &, 003 \\
\cline { 2 - 3 } & Normatif Bağ|ıı &, 024 \\
\hline
\end{tabular}

İş tatmini ve örgütsel bağılıı ile unvan arasında istatistik açıdan pozitif yönde ve anlamlı ilişki olduğu görülmüştür. Genel iş tatmini $p, 006$; içsel tatmin p, 017; dısssal tatmin p, 003; toplam örgütsel bağılık p, 002; duygusal bağlılık $p, 006$; devam bağ|ıı̆ğı $p, 003$ ve normatif bağılı̆ı̆ın $p$ değeri ,024 olarak ortaya çıkmıştır. Böylece, "H6: İş tatmini ve örgütsel bağlılık ile unvan arasında, istatistik açıdan pozitif yönde ve anlamlı bir ilişki vardır", hipotezi kabul edilmiştir. 
Tablo 5: İş Tatmini ve Örgütsel Bağlılık ile Çalışma Süresi Arasındaki Korelasyon

\begin{tabular}{|ll|c|}
\hline & Çalışma Süresi & p \\
\hline Genel İş Tatmini & İçsel Tatmin &, 217 \\
\cline { 2 - 3 } & Dışsal Tatmin &, 215 \\
\hline \multirow{2}{*}{ Toplam Örgütsel Bağıılık } & &, 298 \\
\hline & Duygusal Bağlılık &, 017 \\
\cline { 2 - 3 } & Devam Bağlı̆ı̆ı &, 029 \\
\cline { 2 - 3 } & Normatif Bağlılık &, 022 \\
\hline
\end{tabular}

Yapılan korelasyon analizi sonucunda, çalışma süresi ile gerek genel iş tatmini gerekse alt boyutları olan, içsel ve dışsal tatmin arasında anlamlı bir ilişki olmadığı sonucuna ulaşılmıştır. Toplam örgütsel bağlılığın ise, $p$ değeri ,017 iken, duygusal bağlılık p değeri ,029; normatif bağlılık p değeri ,022 anlamlılık düzeyindedir. Ancak çalışma süresi ile örgütsel bağııı̆ın alt boyutlarından olan devam bağlılığı arasında istatistik açıdan anlamlı bir ilişki olmadığı görülmüştür. Bu durumda; "H7: İş tatmini ve örgütsel bağlılık ile çalışma süresi arasında, istatistik açıdan pozitif yönde ve anlamlı bir ilişki vardır", hipotezi şu şekilde yapılandırılabilir:

H7a: İş tatmini ile çalışma süresi arasında, istatistik açıdan pozitif yönde ve anlamlı bir ilişki vardır, hipotezi reddedilmiştir.

H7b: Örgütsel bağ|ıık ile çalışma süresi arasında, istatistik açıdan pozitif yönde ve anlamlı bir ilişki vardır, hipotezi kabul edilmiştir.

Tablo 6: İş Tatmini ve Örgütsel Bağlılık ile Gelir Arasındaki Korelasyon

\begin{tabular}{|ll|c|}
\hline \multirow{2}{*}{ Gelir } & p \\
\hline Genel İş Tatmini & &, 004 \\
\hline \multirow{3}{*}{ Toplam Örgütsel Bağılıık } & İçsel Tatmin &, 005 \\
\cline { 2 - 3 } & Dışsal Tatmin &, 006 \\
\hline & &, 045 \\
\cline { 2 - 3 } & Duygusal Bağ|ılık &, 051 \\
\cline { 2 - 3 } & Devam Bağ|ı̆ı̆ı &, 142 \\
\cline { 2 - 3 } & Normatif Bağ|ılık &, 113 \\
\hline
\end{tabular}

Gelir ile iş tatmini ve örgütsel bağlılık faktörleri arasında pozitif yönde anlamlı bir ilişki olduğu görülmektedir. Böylece, "H8: İş tatmini ve örgütsel bağlılık ile gelir arasında, istatistik açıdan pozitif yönde ve anlamlı bir ilişki vardır”, hipotezi kabul edilmiştir. Gelirin, çalışanların içsel ve dışsal tatminlerini olumlu yönde etkilediği, örgütsel bağıııklarını artırdığı çıkan analiz sonuçlarıdır. Genel tatmin düzeyi $(p, 004)$ ile bunun alt faktörleri olan içsel tatmin $(p, 005)$ ve dışsal tatmin $(p, 006)$ boyutları arasında da anlamlı sonuçlara ulaşılmıştır. Toplam örgütsel bağlılık $(p, 045)$ ile gelir arasında anlamlı bir ilişki söz konusu iken, alt boyutları açısından bu anlamlılık desteklenmemiştir.

\section{SONUÇ VE DEĞERLENDIRME}

Örgüt-çalışan ilişkisi sonucunda oluşan örgütsel bağlıık, çalışanın örgüte karşı hissettiği bağın gücünü ve çalışanın örgüte olan psikolojik yaklaşımını ifade etmektedir. Bu noktada bağlıık, bireyler örgütleriyle özdeşleştiklerinde, örgütsel amaç ve değerler yönünde çaba sarf ettiklerinde ortaya çıkmaktadır (Sözmez, 2014:54). Farklı faktörlerin örgütsel bağıılığa olumlu ya da olumsuz etkisi ve ilişkisi yönünde yapılan araştırmaya 
göre; örgütsel bağlılık boyutlarının, çalışanlarda öncelikle duygusal bağlıık, sonra sürekli bağ|ııı ve son olarak da normatif bağııı̆ının olması gerektiği yönünde bulgulanmıştır (Arı, 2015:19-20). Çalışanın kendini tamamiyle işine vermesi durumu olarak ifade edilen örgütsel bağlılığın oluşması ayrıca işten duyulan memnuniyet olarak değerlendirilen iş tatmini ile de yakından ilişkilidir. Örgütsel bağılıık ve iş tatmini arasındaki pozitif ilişki gerek literatürdeki bulgularla gerekse bu araştırma bulguları ile yüksek korelasyona sahip olduğu yönünde desteklenmiştir. Benzer normlara sahip olan kuşak grupları benzer iş değerleri ve iş tutumu hususunda da aynı özellikleri gösterebilmektedirler (Torun ve Çetin, 2015:139). Bu noktada çalışma X ve $Y$ kuşağı perspektifinden tatmin ve bağ|lıı unsurları ve aralarındaki ilişkinin yönü itibariyle irdelenmiştir. Literatürde bu konuda gerçekleştirilen araştırmalar ile bu çalışmada elde edilen sonuçlar birbirini desteklememiştir. Araştırmamızda, $X$ ve $Y$ kuşağının örgütsel bağlıık ve iş tatmininin farklılaşmadığı bulgusuna ulaşılmıştır. Bu sonuç kuşaklar konusunda yapılan eleştirel yaklaşımı akla getirmektedir. Kuşakların tutum ve değerlerinde meydana gelen bir takım farklılıkların yaşam evrelerinden (çocukluk, gençlik, yetişkinlik, yaşııık vb.) kaynaklandığı yönündedir. Kuşak ayrımının daha temel değişkenler ile ayrıştırıması gerektiğidir. Örneğin; yaş (bireyin olgunlaşmasından veya hayat evrelerindeki değişikliklerden kaynaklanan farklılaşmalar), tarihsel dönem (belirli dönemlerde yaşanan olaylardan kaynaklanan farklııklar) ve kohort (benzer sıkıntıları ve deneyimleri yaşamıs kişilerin oluşturduğu topluluklardan kaynaklanan farklılıklar) değişkenleri noktasında daha belirgin ele alınması gerektiğidir (Gürbüz, 2015). Bu nedenle çalışmada ele alınan örneklemin kuşaklar bağlamında, daha belirgin özellikleri yansıtıp yansıtmadığı çözümlenememiştir. Bu konu gelecek çalışmalar açısından da net çizgilerin belirlenebilmesi bakımından öneri oluşturmaktadır.

Hipotez testleri ile sınanan araştırma sonuçlardan elde edilen diğer veriler şu şekildedir:

İş tatmini ve örgütsel bağlılık ile unvan arasında istatistik açıdan pozitif yönde ve anlamlı ilişki olduğu görülmüştür. İ̧̧ tatmini ve örgütsel bağlılık ile tüm alt boyutların sınandığı istatistiki verilerde kuşak, cinsiyet, medeni durum ve çocuk sayısı arasında anlamlı sonuçlara ulaşılamamışır. Yapılan korelasyon analizi sonucunda, çalışma süresi ile iş tatmini arasında anlamlı bir ilişki olmadığı, ancak, örgütsel bağııık arasında anlamlı sonuçlar olduğu bulgulanmıştır. Gelir ile iş tatmini ve örgütsel bağlılık faktörleri arasında pozitif yönde anlamlı bir ilişki olduğu görülmektedir.

\section{KAYNAKÇA}

Adıgüzel, O.; Batur, H. Z.; Ekşili, N. (2014), Kuşakların Değişen Yüzü ve Y Kuşağı İle Ortaya Çıkan Yeni Çalışma Tarzı:Mobil Yakalılar, Süleyman Demirel Üniversitesi Sosyal Bilimler Enstitüsü Dergisi, 1(19): 165-182.

Akıncı, Z. (2002), Turizm Sektöründe İşgören İş Tatminini Etkileyen Faktörler: Beş Yıldızlı Konaklama İşletmelerinde Bir Uygulama, Akdeniz i.i.B.F. Dergisi, 4: 1-25.

Aksu, N. (2012), İ̧̧ Tatmininin Bazı Demografik Değişkenler Açısından İncelenmesi, Polis Bilimleri Dergisi, 14 (1): $59-80$.

Akşit Aşık, N. (2010), Çalışanların İş Doyumunu Etkileyen Bireysel Ve Örgütsel Faktörler İle Sonuçlarına iliş̧kin Kavramsal Bir Değerlendirme, Türk İdare Dergisi, Haziran 467: 31-51.

Albdour, A. A.;Altarawneh, I. I. (2014), EmployeeEngagementandOrganizationalCommitment: Evidencefrom Jordan, International Journal Of Business, 19 (2): 193-212.

Allen, N. J.;Meyer, J. P., (1993), OrganizationCommitment: Evidence Of CareerStageEffects?, Journal Of Business Research, 26 (1): $49-61$.

Alparslan, A. M.; Sezgin, O. (2014), “Y Kuşağı” Çalışanları İşyerinde Neden Gönüllü Davranışlar Sergiler?, Melikşah Üniversitesi, 2. Örgütsel Davranış Kongresi Bildiriler Kitabı, 7-8 Kasım, Kayseri, s. 841-847.

Arı, A. (2015), Beden Eğitimi Ve Spor Yüksekokulu Akademisyenlerinin Örgütsel Adalet Algıları İle Örgütsel Bağlılık Düzeyleri Arasındaki İlişki, Yüksek Lisans Tezi, Selçuk Üniversitesi Sağlık Bilimleri Enstitüsü Spor Yöneticiliği Anabilim Dalı, Konya, s. 93.

Aziri, B. (2011), JobSatisfaction: A LiteratureReview, Management Research andPractice, 3 (4): 77-86.

Bayrak Kök, S. (2006), İş Tatmini Ve Örgütsel Bağlılığın İncelenmesine Yönelik Bir Araştırma, Atatürk Üniversitesi İktisadi ve İdari Bilimler Dergisi, 20 (1): 291-310. 
Cox, J.;Holloway, M. (2010), Multi-Generational Team BuildingInToday'sWork Environment, International Handbook of Academic Research AndTeaching, Intellectbase International Consortium, Academic Conference, Nashville, TN, May 27-29, IntellectualPerspectives\& MultiDisciplinaryFoundations, 10: 61-68.

Çarıkçı, İ. H. (2000), Çalışanların İş Tatminlerini Etkileyen Kişisel Özellikler Süpermarket Çalışanları Üzerinde Bir Araştırma, Süleyman Demirel Üniversitesi İktisadi ve İdari Bilimler Fakültesi, 5 (2): 155-168.

Da Silva,C. R.;Dutra, J. S.; Veloso, E. F. R.; Fischer, A. L.; Trevisan, L. N. (2015), GenerationalPerceptionsAndTheirinfluences On OrganizationalCommitment,Management Research: TheJournal of thelberoamerican Academy of Management,13(1): 5-30.

Dağdeviren Gözen, E. (2007), İş Tatmini Ve Örgütsel Bağlılık Sigorta Şirketleri Üzerine Bir Uygulama, Yüksek Lisans Tezi, Atılım Üniversitesi Sosyal Bilimler Enstitüsü İşletme Anabilim Dalı, Ankara.

Gürbüz, S. (2015), Kuşak Farklılıkları: Mit mi, Gerçek mi?, İ̧̧ ve İnsan Dergisi, Nisan, 2 (1): 39-57.

Herley, W. (2009), MotivatingtheGenerations: EconomicandEducationallnfluences, Journal of Inquiry\& Action in Education, 3(1): 1-14.

Herzberg, F. (1987), OneMore Time: How Do YouMotivateEmployees?” Harvard Business Review, Yeni Baskı Numarası: 87507, Eylül-Ekim, 1987, s. 5-16

Judge, T. A.;Klinger, R. (2008), TheScience Of SubjectiveWell-Being, JobSatisfactionSubjectiveWell-Being at Work, (Ed.: Michael Eıd\&Randy J. Larsen), - TheGuilfordPress: New York: 393-413.

Karaaslan, S. (2014), Kuşaklararası Farklılıkları Örgütler Üzerinden Anlamak: Bir Alan Araştırması, Ankara Üniversitesi Sosyal Bilimler Enstitüsü Halkla İlişkiler Ve Tanıtım Anabilim Dalı Ankara.

Karcıoğlu, F.; Türker, E. (2010), Psikolojik Sözleşme ille Örgütsel Bağlılık İlişkisi: Sağlık Çalışanları Üzerine Bir Uygulama”, Atatürk Üniversitesi İktisadi ve İdari Bilimler Dergisi, 24 (2): 121-140.

Kaur, K. ; Sandhu, H. S. (2010), CareerStageEffect on OrganizationalCommitment: EmpiricalEvidencefromlndianBankingIndustry, International Journal of Business and Management, December, 5 (12): 141-152.

Keleş H. N. (2011), Y kuşağı çalışanlarının motivasyon profillerinin Belirlenmesine Yönelik Araştırma, Organizasyon Ve Yönetim Bilimleri Dergisi, 3 (2): 129-139

Khanolkar, R. S. (2013), Influence of EmployerBranding on SatisfactionandCommitment of Generation Y Employees, IOSR Journal of Business and Management (IOSR-JBM), e-ISSN: 2278-487X, p-ISSN: 2319-7668: 13-18.

Kian, T. S.;Yusoff, W. F. (2012), Generatıon X And Y AndTheirWorkMotivation, Proceedings International Conference of Technology Management Business andEntrepreneurship, Malaysia 18-19 Dec: 396-408.

Koç, M.; Öztürk, L.; Yıldırım, A.; Sağtaş, S. (2015), Y Kuşağının İş Tatmininde Motivasyonun Modellemesi (Kahramanmaraş illinde Bir Uygulama), 14. Ulusal İşletmecilik Kongresi, Aksaray, 7-9 Mayıs: 492-498.

Mert, I. S. (2010), İş Tatmini Alt Boyutlarının Örgütsel VatandaşlıkDavranışı Üzerindeki Etkisi: Yöneticiler Üzerine BirAraştırma, Savunma Tıp Dergisi 9 (2): 117-143.

Meyer, J.P.;Allen, N.J. (1991), A Three-Components Conceptualization of OrganizationalCommitment, Human Resource Management Review, 1 (1): 61-89.

Öz, Ü. (2015), Xyz Kuşaklarının Özellikleri Ve Y Kuşağının Örgütsel Bağlılık Düzeyi Analizi, Yüksek Lisans Tezi, Atılım Üniversitesi Sosyal Bilimler Enstitüsü Ankara.

Öztürk, M. (2013), Örgütsel Bağlılık Ve Sağıık Çalışanlarının Örgütsel Bağlılık Düzeyleri (Kırklareli Örneği), Yüksek Lisans Tezi, Beykent Üniversitesi Sosyal Bilimler Enstitüsü İşletme Yönetimi Ana Bilim Dalı Hastane Ve Sağlık Kurumları Yönetimi Bilim Dalı, İstanbul.

Peitzmeier, T. (2011), Comparison Study:Generational Perceptıons of Competencies of ParksandRecreationProfessionals", A ThesisPresentedToTheDepartment of Health, PhysicalEducation, Recreation, andDancelnCandidacy For TheDegree of Master of Science (Final Thesis), NorthwestMissouriStateUnıversityMaryville, Missouri, July: 47.

Rajput, N.;Marwah, P.; Balli, R.; Gupta, M. (2012), Maintaining Gen X-Gen Y: A Study Of Work-Life Balance, An International Multidisciplinary Research Journal, July, 2(7): 1-16.

Robbins, S. P.;Judge, T. A. (2013), Örgütsel Davranış, (Çev. İnci Erdem), Nobel Akademik Yayıncılık, 14. Basımdan çeviri-Nisan, Ankara: 666.

Sönmez H. (2014), Değişim Yaşanan Örgütlerde İş Tatmini İle Örgütsel Bağlılık İlişkisi, Yüksek Lisans Tezi, Ege Üniversitesi Sosyal Bilimler Enstitüsü İşletme Anabilim Dalı Yönetim Bilimi Ve Organizasyon Bilim Dalı İzmir.

Torun, Y.; Çetin, C. (2015), Örgütsel Sinizmin Kuşaklar Bazında Değerlendirilmesi: Kuşaklara Göre Örgütsel Sinizmin Hedefinde Ne Var?, İ̧̧ ve İnsan Dergisi, Ekim, 2 (2): 137-146. 